\title{
The Perceived Meanings of Tokopedia Advertisement Video, "Berikan yang Paling Berarti untuk yang Berarti"
}

\author{
Novelyn, L. \\ English Department, Faculty of Letters, Petra Christian University, Siwalankerto 121-131, Surabaya \\ 60236, INDONESIA \\ lornadnw@gmail.com
}

\begin{abstract}
Delivering a message from an advertisement is important to know whether the message that a company wants to transfer is well-delivered or not because the background of audiences may affect them in interpreting the message. Thus, the writer aims to the writer aims to discover how background education affects people to produce information by observing the perceived meanings produced by English Department respondents and Engineering Department respondents. To do so, the writer uses verbal and non-verbal communications Tokopedia "Berikan yang Paling Berarti untuk yang Berarti" advertisement video. The writer applies Saussure's process of signification and Peirce's three sign mode to analyze the perceived meanings from the respondents. Based on the analysis, the writer discovers all respondents mainly use symbolic mode in producing messages which means the respondents interpret the data by relating it with their personal association. Nonetheless, Engineering Department's respondents use indexical mode more often than English Department's respondents in producing some meanings. Thus, the writer sees that English Department respondents mostly produce moral messages while Engineering Department respondents just mention the storyline. In conclusion, background knowledge indeed affects people to perceive meanings.
\end{abstract}

Keywords: Process of Signification, Perceived Meaning, Verbal and Non-verbal Communication.

\section{INTRODUCTION}

In marketing the brand of the company, advertising takes an important role to introduce the product, to give information, and to persuade the customer to use the product. It is well said by Koekemoer (as cited in Busen \& Mustaffa, 2014) who defines advertising as "any paid form of mass presentation of ideas, products, and services by an advertiser, addressed to selected target audiences to create awareness, inform, remind, influence, and persuade them to buy the product or service or to be favorably inclined towards those ideas, products, or services". Through advertising, the company can communicate well with the customer about its product because advertising is an informative and persuasive way of communication. Hence, advertisement has become a medium of persuasion to promote something that has social and economic values such as service, goods, health, and so on. To make the brand of the product well known, the company advertises the product by using the channel of communication which has four sub-categories such as print media, broadcast media (TV, radio, cinema), outdoor, and sales promotion to spread the advertisements. The advertisement takes various forms based on the channel of communication used like a brochure, digital poster, printed poster, or commercial video.

In this research, the writer will use Tokopedia's advertisement video of "Berikan yang Paling Berarti untuk yang Berarti" which is translated into "Give the Most Meaningful to Whom It Matters" (GMMWM). The advertisement videos use the current slogan which is \#JustStartFirst. The slogan \#JustStartFirst conveys the message of a call for action that the audience's dream can come true if she or he tries to start it first (Gunawan, 2018). Tokopedia and Flock target the young adults as their audience who are still active and passionate to dream 
Novelyn: The Perceived Meanings of Tokopedia Advertisement Video, "Berikan yang Paling Berarti untuk yang Berarti”

and make it come true. Tokopedia produces a lot of advertisement videos with its slogan \#JustStartFirst, yet, the video commercial "GMMWM" implicitly promotes its product or service.

Through the chosen video commercial, the writer wants to find out what the respondents' perceptions of "GMMWM" in advertisement video are. The writer chooses five verbal data that relate to time and five non-verbal data which support the verbal data. She determines time wordrelated because time value is the point that wants to be delivered through the title "GMMWM". In her research, the writer also involves ten respondents to help enrich this research. The ten respondents consist of five respondents majoring in engineering and five respondents majoring in English Department. The writer decides to involve five Engineering Department and English Department respondents because the background education of each major is different. Engineering students deal with exact science and technology which may affect their way of thinking. Meanwhile, English Department respondents learn something abstract such as culture and language that makes the way of thinking of English Department students more abroad. According to Mustansyir (2003), technology and science limit people to explain something abstract without providing the evidence to get the exact answer. Thus, the writer wants to find out what the perceived meanings are produced by ten audiences with the different majors of study. The writer is interested to do this research because audiences may perceive the meaning of the video advertisement differently from each other. The writer wants to find out how audiences decode Tokopedia advertisements with respondents' different background education.

To understand the perceived meaning of video advertisement "GMMWM", the writer applies the process of the signification of Saussure and Peirce's three sign modes written by Chandler. Chandler (2007) explained that the process of signification is a process to describe the relationships between the signifier and the signified. A signifier is a form that the sign takes, while signified means a concept suggested by the signifier. In another word, signifier represents how people call things in reality, and signified means the concept or the actual object in reality. Moreover, Peirce's three sign modes are symbolic, icon, and index. Symbolic mode means a mode in which the signifier does not resemble the signified but which is purely conventional. The interpretation in symbolic mode explains that the interpretation is obtained by relating the meaning with a personal association or a law to be agreed upon and learned. For example, the colors used in traffic lights indicate meaning that all people share general knowledge. Red symbolizes that a driver needs to stop while green means to go through. The second mode is iconic which the signifier is perceived as resembling or imitating the signified in recognizably looking, sounding, tasting, or smelling (Chandler, 2207, p.36). A cartoon is an example of icon mode. In cartoons, we can see a lot of things resembling animals, celebrities, etc. When the audience sees a horse in a cartoon, he or she can identify if that character is a horse. Then, an index is a mode in which the signifier is not arbitrary but is directly connected in physically or causally way to the signified regardless of intention. According to Peirce, an index is a sign used to indicate something. For instance, a person sees smoke because of a burning house. The smoke is an index that indicates something is burning up.

\section{METHODS}

This research is conducted using a descriptive qualitative analysis method to analyze the perceived meaning of Tokopedia's advertisement video "GMMWM". The writer chooses to use a qualitative approach because it is the most suitable approach to be used since the data are the responses of respondents toward the video commercial that will be transcribed. To elaborate on perceived meaning, the writer also intended to reveal the process of the signification of the respondents' perceived meanings. 
The data is collected by interviewing ten respondents with questions about verbal data and non-verbal data. The writer asks five respondents from English Department and five respondents from Engineering Department. Then, the writer classified the answers into a table for analyzing it. The writer provides a table to help her organize the data and to understand the data analysis easily. Then, the writer discusses the data furthermore in the form of paragraphs.

\section{FINDINGS AND DISCUSSION}

\section{English Department}

Table 1 "Promise a special dream" perceived meanings of verbal data

\begin{tabular}{|c|c|c|c|c|c|}
\hline $\begin{array}{l}\text { Verbal } \\
\text { Data }\end{array}$ & Respondents & $\begin{array}{l}\text { Perceived } \\
\text { Meaning }\end{array}$ & Signifier & Signified & Modes \\
\hline \multirow[t]{2}{*}{$\begin{array}{l}\text { Promise a } \\
\text { special } \\
\text { dream }\end{array}$} & $\begin{array}{l}\mathrm{R} 1, \mathrm{R} 2 \text {, and } \\
\mathrm{R} 3\end{array}$ & $\begin{array}{l}\text { Berhubungan } \\
\text { soalnya } \\
\text { "Janjikan } \\
\text { mimpi yang } \\
\text { teristimewa" } \\
\text { artinya kayak } \\
\text { harus } \\
\text { menghargai } \\
\text { waktu karena } \\
\text { waktu itu yang } \\
\text { teristimewa. } \\
\\
\text { [Related } \\
\text { because } \\
\text { "Promise a } \\
\text { special dream" } \\
\text { conveys a } \\
\text { message to } \\
\text { appreciate time } \\
\text { because of its } \\
\text { preciousness.] }\end{array}$ & $\begin{array}{l}\text { Promising } \\
\text { something } \\
\text { best or } \\
\text { memorabl } \\
\text { e. }\end{array}$ & $\begin{array}{l}\text { The special } \\
\text { dream is the } \\
\text { time } \\
\text { because it is } \\
\text { precious; } \\
\text { thus, people } \\
\text { should } \\
\text { appreciate } \\
\text { the time. }\end{array}$ & Symbolic \\
\hline & R4 & $\begin{array}{l}\text { Tidak secara } \\
\text { langsung } \\
\text { berhubungan } \\
\text { karena jam } \\
\text { yang sempurna } \\
\text { itu adalah } \\
\text { impiannya si } \\
\text { ayah dan jam } \\
\text { sempurna itu } \\
\text { membutuhkan } \\
\text { proses yang } \\
\text { panjang. } \\
\text { [Not directly } \\
\text { related. Not } \\
\text { only, the }\end{array}$ & $\begin{array}{l}\text { The father } \\
\text { promises a } \\
\text { special } \\
\text { watch. }\end{array}$ & $\begin{array}{l}\text { To make } \\
\text { something } \\
\text { special, } \\
\text { there needs } \\
\text { lots of time } \\
\text { and effort. }\end{array}$ & Symbolic \\
\hline
\end{tabular}


Novelyn: The Perceived Meanings of Tokopedia Advertisement Video, "Berikan yang Paling Berarti untuk yang Berarti”

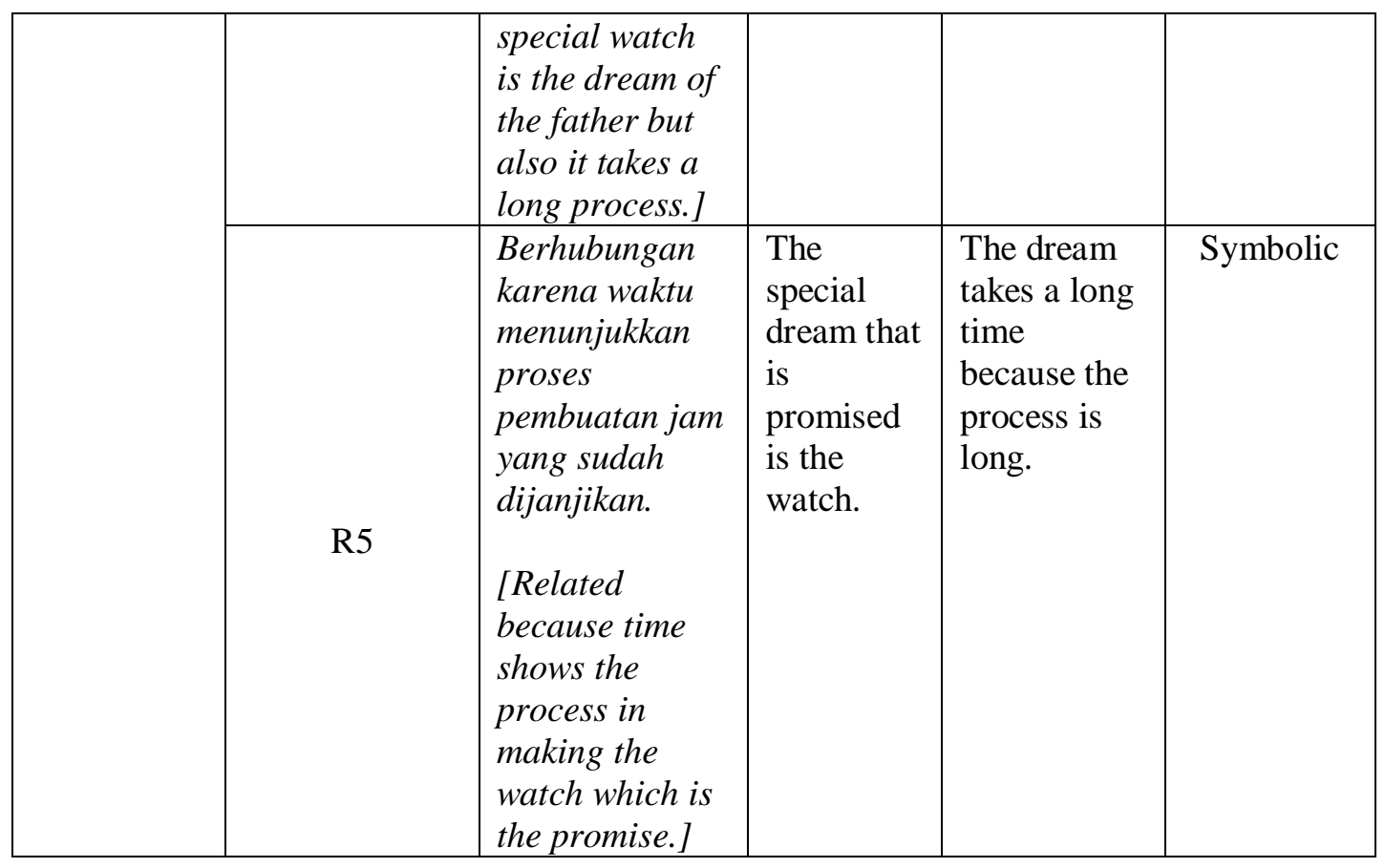

The writer identifies that the respondents interpret the caption "Promise a special dream" differently. R1, R2, and R3 believe if the caption relates to time and they interpret the caption as precious time. $\mathrm{R} 1$ considers the caption is likely to remind the father to value time by saying that people need to live in the time being, to appreciate time because time runs so fast. R2 also thinks that time needs to be appreciated. R2 and R3 consider that time is supposed to be the gift, not the watch. The meaningful thing is not an object but is a moment. Therefore, the writer sees from R4's perceived meaning that the caption does not directly relate to time because R4 underlines that the perfect watch is the father's dream. R4 thinks if the caption means that the father does not promise to his son to make a meaningful dream. The caption reflects the father's dream to make a meaningful thing. However, R4 thinks that the father has wasted his time to make the watch. In contrast to R4, R5 believes that the caption relates to time. R5 thinks that the father has already promised his son to give him a special watch. To make it special, the watch takes a lot of time to be done. Thus, the writer sees that all the interpretations above use symbolic as mode because each respondent relates the meaning with their personal experiences.

Table 2 "Promise a special dream" perceived meanings of non-verbal data

\begin{tabular}{|c|c|c|c|c|c|}
\hline Non-verbal Data & $\begin{array}{l}\text { Respondent } \\
\text { S }\end{array}$ & $\begin{array}{l}\text { Perceived } \\
\text { Meaning }\end{array}$ & Signifier & Signified & Modes \\
\hline & $\begin{array}{l}\mathrm{R} 1, \mathrm{R} 2, \mathrm{R} 4 \\
\text { and } \mathrm{R} 5\end{array}$ & $\begin{array}{l}\text { Digambarkan } \\
\text { dengan bunga } \\
\text { mekar yang } \\
\text { menunjukkan } \\
\text { proses untuk } \\
\text { mendapatkan } \\
\text { yang spesial. } \\
\text { [Portrayed as the } \\
\text { blooming flower } \\
\text { which shows the } \\
\text { process to get }\end{array}$ & $\begin{array}{l}\text { The } \\
\text { blooming } \\
\text { flower } \\
\text { represents } \\
\text { the caption. }\end{array}$ & $\begin{array}{l}\text { The } \\
\text { blooming } \\
\text { flower } \\
\text { shows the } \\
\text { process to } \\
\text { get } \\
\text { something } \\
\text { special. }\end{array}$ & $\begin{array}{c}\text { Symboli } \\
\text { c }\end{array}$ \\
\hline
\end{tabular}




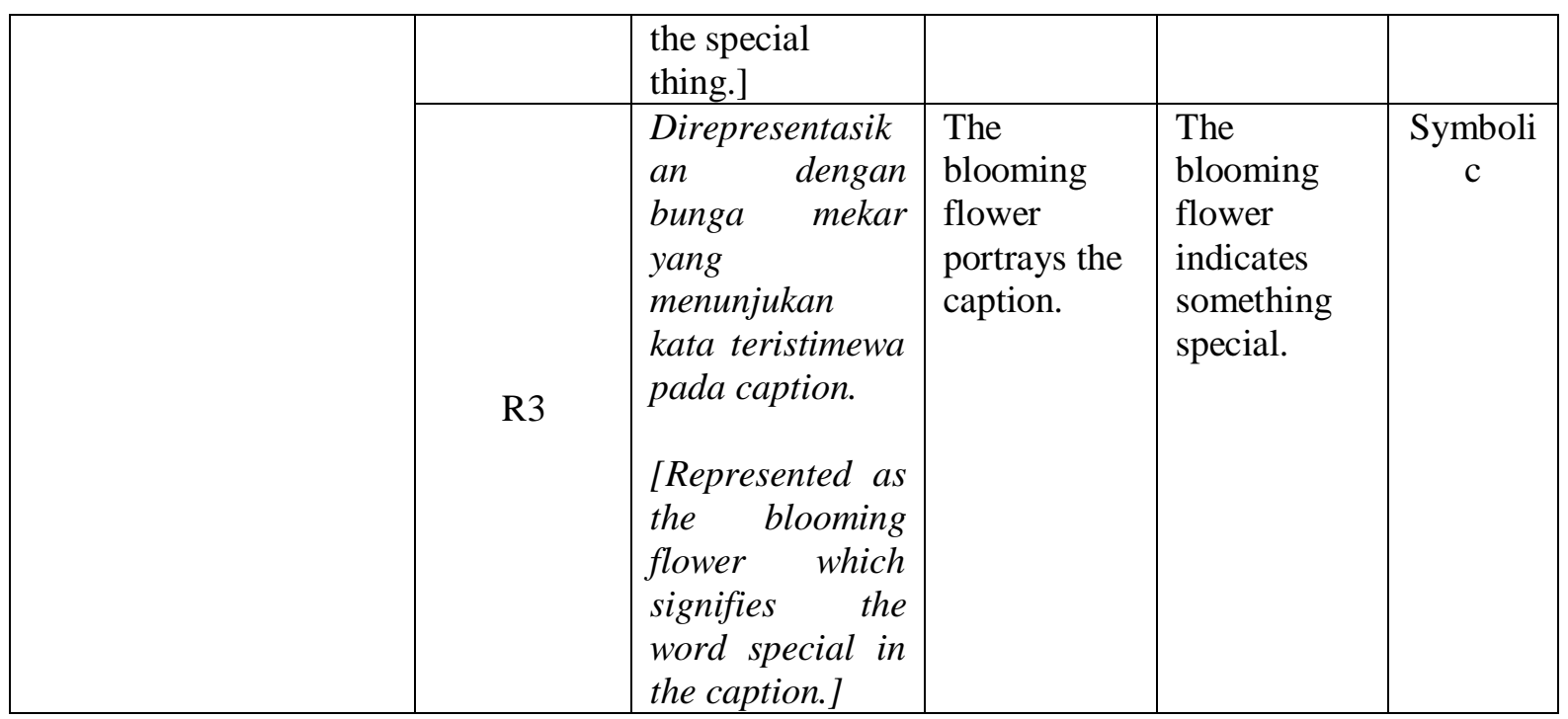

R1 thinks the blooming flower is more special by providing a comparison with the bud of flowers. People will wait for the bud to bloom because the blooming flower shows the process of how the flower grows good blooms as can be seen in its color and its shape. R1 indirectly describes that time is precious so that people should appreciate it as the blooming flower-like R1 explains in table 5. R2 interprets the process by saying it as quality time. The flower is blooming nicely through the process of watering and nourishing. Thus, watering and nourishing is the time that the father needs to spend with his son to have special moments with him according to R2. Therefore, R4 and R5 consider that to be bloomed and beautiful, the flower needs a process. R4 and R5 think that the flowering plant is perfect or special when the plant has flowered because it is the purpose to have the flowering plant. R3 considers the blooming flower as the representative of the caption "Promise a special dream". Then, according to R3, the blooming flower represents something special. R3 does not know what type of flower is but R3 assumes that the flower may bloom once in a year to signify the word special in the caption. When a flower blooms once a year, people will appreciate it because it is special. The writer sees that R1, R2, R3, R4, and R5's perceived meanings show that the model used is symbolic because, from their explanation, they include their personal experiences in interpreting the meaning.

\section{Engineering Department}

Table 3 "Promise a special dream" perceived meanings of verbal data

\begin{tabular}{|c|c|c|c|c|c|}
\hline $\begin{array}{l}\text { Verbal } \\
\text { Data }\end{array}$ & Respondents & $\begin{array}{l}\text { Perceived } \\
\text { Meaning }\end{array}$ & Signifier & Signified & Modes \\
\hline $\begin{array}{l}\text { Promise a } \\
\text { special } \\
\text { dream }\end{array}$ & $\mathrm{R} 6$ and $\mathrm{R} 7$ & $\begin{array}{l}\text { Tidak secara } \\
\text { langsung } \\
\text { berhubungan } \\
\text { karena, untuk } \\
\text { mendapatkan jam } \\
\text { yang sempurna } \\
\text { seperti yang } \\
\text { sudah dijanjikan } \\
\text { si ayah, } \\
\text { membutuhkan } \\
\text { waktu yang lama. }\end{array}$ & $\begin{array}{l}\text { The father } \\
\text { promises } \\
\text { his son } \\
\text { that he } \\
\text { will give } \\
\text { the best } \\
\text { thing. }\end{array}$ & $\begin{array}{l}\text { The time } \\
\text { process in } \\
\text { making the } \\
\text { special } \\
\text { watch is } \\
\text { what makes } \\
\text { the gift } \\
\text { special. }\end{array}$ & Index \\
\hline
\end{tabular}


Novelyn: The Perceived Meanings of Tokopedia Advertisement Video, "Berikan yang Paling Berarti untuk yang Berarti”

\begin{tabular}{|c|c|c|c|c|}
\hline & $\begin{array}{l}\text { [Not directly } \\
\text { related because, } \\
\text { to get the perfect } \\
\text { watch which is } \\
\text { promised by the } \\
\text { father, it takes } \\
\text { lots of time.] }\end{array}$ & & & \\
\hline $\mathrm{R} 8$ and $\mathrm{R} 9$ & $\begin{array}{l}\text { Berhubungan } \\
\text { soalnya si ayah } \\
\text { memberikan } \\
\text { waktunya untuk } \\
\text { membuat jam. } \\
\text { [Related because } \\
\text { the father gives } \\
\text { his time to make } \\
\text { the watch.] }\end{array}$ & $\begin{array}{l}\text { A person } \\
\text { will give } \\
\text { something } \\
\text { special to } \\
\text { someone } \\
\text { special. }\end{array}$ & $\begin{array}{l}\text { The father } \\
\text { gives his } \\
\text { time to } \\
\text { make the } \\
\text { watch. }\end{array}$ & Index \\
\hline R10 & $\begin{array}{l}\text { Berhubungan } \\
\text { soalnya si ayah } \\
\text { sibuk dalam } \\
\text { membuat jam. } \\
\\
\text { [Related because } \\
\text { the father is busy } \\
\text { making the } \\
\text { watch.] }\end{array}$ & $\begin{array}{l}\text { The father } \\
\text { promises } \\
\text { that he } \\
\text { will go on } \\
\text { holiday } \\
\text { with his } \\
\text { son. }\end{array}$ & $\begin{array}{l}\text { The father } \\
\text { delays the } \\
\text { holiday } \\
\text { because he } \\
\text { is busy to } \\
\text { make the } \\
\text { watch. }\end{array}$ & Index \\
\hline
\end{tabular}

R6 and R7 underline the caption is indirectly related to time. R6 thinks the time and sacrificing time are different. R6 considers the sacrificing time in making the special thing is the precious one. Thus, R7 interprets the caption by giving the special gift which is the watch, not the time. R7 thinks that, in making a good watch, the watch is made in a long time. R8 and R9 agree that the caption is related to time because the father gives his time to make the promised watch. According to R8, the father focuses on working the watch which takes a long time to make the perfect watch to fulfill his promise. R9 also thinks the relationship between the caption and time can be seen from the father who gives his time to make that special. Therefore, R10 agrees that the caption and time are connected because the father is busy making the watch. The father delays his vacation to make the watch which his son does not want. From table 3, the writer thinks the perceived meanings are considered in index mode. The special watch is there because the father spends his time making the special watch.

Table 4 "Promise a special dream" perceived meanings of non-verbal data

\begin{tabular}{|c|c|c|c|c|c|}
\hline Non-verbal Data & $\begin{array}{l}\text { Respondent } \\
\text { S }\end{array}$ & $\begin{array}{l}\text { Perceived } \\
\text { Meaning }\end{array}$ & Signifier & Signified & Modes \\
\hline & $\begin{array}{l}\text { R6, R7, } \\
\text { and R8 }\end{array}$ & $\begin{array}{l}\text { Disimbolkan } \\
\text { dengan bunga } \\
\text { mekar karena } \\
\text { bunga itu } \\
\text { istimewa saat } \\
\text { mekar. } \\
\text { [Signified as the }\end{array}$ & $\begin{array}{l}\text { The } \\
\text { blooming } \\
\text { flower } \\
\text { represents } \\
\text { the caption. }\end{array}$ & $\begin{array}{l}\text { The } \\
\text { blooming } \\
\text { flower } \\
\text { indicates } \\
\text { something } \\
\text { special } \\
\text { because } \\
\text { when the }\end{array}$ & $\begin{array}{c}\text { Symboli } \\
\text { c }\end{array}$ \\
\hline
\end{tabular}




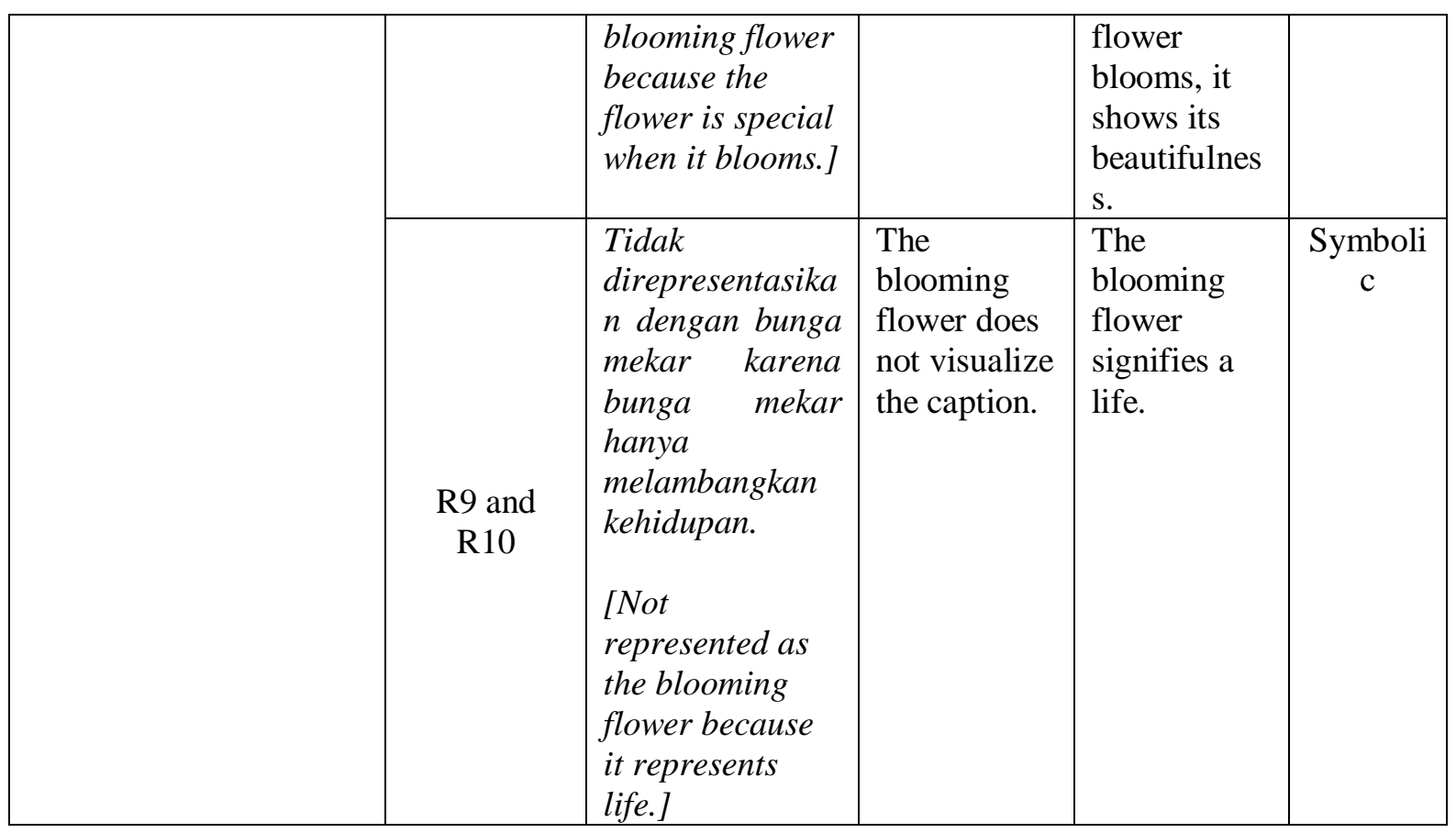

In this section, the writer discovers that there are two analyses in grouping the perceived meanings. R6, R7, and R8 believe that the blooming flower represents the caption because it shows how special the blooming flower is. R6 and R7 explain that the blooming flower is the goal of the flowering plant. Moreover, R7 compares the blooming flower and the bud. According to R7, a flower that blooms is prettier rather than the bud one. R8 thinks that the blooming flower signifies special because the blooming flower shows its glamour. R8 also connects this picture to the scene after where the grandchild is born. In contrast, R9 and R10 believe that the blooming flower does not represent the caption. R9 and R10 think that the flower shows a life where people are growing up from young to old. According to R9, the son has his own family which proves how life keeps running and people grow up. Then, R10 thinks that the blooming flower indicates a life so that the flower does not relate to the caption. From table 16, the writer sees that the five respondents above apply their personal association in interpreting the sign's meanings so that their perceived meanings are categorized in symbolic mode.

\section{Differences and Similarity}

The first difference is that Engineering Department's respondents tend to give perceptions based on the cause and effect of the storyline than the English Department's respondents. The writer sees that the Engineering Department's respondents mostly apply index mode which sign indicates something. For instance, the perceived meanings from English Department's respondents are categorized in the symbolic mode in producing the meanings of the caption "Promise a special dream" while all perceived meanings by Engineering Department's respondents are classified in index mode (look at table 21). English Department's respondents mainly involve their personal association in interpreting the caption from "GMMWM" advertisement video. The writer also sees how the storyline helps Engineering Department's respondents in producing the meanings based on the data such as the storyline. 
Novelyn: The Perceived Meanings of Tokopedia Advertisement Video, "Berikan yang Paling Berarti untuk yang Berarti”

Table 5 Comparison of mode used by the respondents

\begin{tabular}{|c|c|c|c|c|}
\hline $\begin{array}{l}\text { Verbal } \\
\text { Data }\end{array}$ & Respondents & Modes & Respondents & Modes \\
\hline \multirow{3}{*}{$\begin{array}{l}\text { Promise a } \\
\text { special } \\
\text { dream }\end{array}$} & $\begin{array}{l}\mathrm{R} 1, \mathrm{R} 2 \text {, and } \\
\mathrm{R} 3\end{array}$ & Symbolic & $\mathrm{R} 6$ and $\mathrm{R} 7$ & Index \\
\hline & $\mathrm{R} 4$ & Symbolic & $\mathrm{R} 8$ and $\mathrm{R} 9$ & Index \\
\hline & R5 & Symbolic & R10 & Index \\
\hline
\end{tabular}

The second difference is that all respondents from English Department can explain how Tokopedia promotes its service and how the non-verbal data support the verbal data while, in Engineering Department, some cannot explain them. All English Department respondents are able to explain how Tokopedia promotes itself through "GMMWM" advertisement video. They mention that Tokopedia works as a platform that provides anything to make them not to waste time anymore. Moreover, all English Department can explain how the certain sign in the nonverbal data supports the verbal data. They can provide a well-reasoned explanation. However, three respondents from Engineering Department cannot connect how Tokopedia delivers the marketing message through "GMMWM" advertisement video. Two of them do not mention Tokopedia in the perceived meanings. They just are able to explain how the tagline relates to time. Another one interprets that the commercial video is a campaign video and it tells about the development of Tokopedia. Therefore, some respondents from Engineering Department respondents also do not agree for several pictures from non-verbal data support the verbal data. They cannot see a way that connects the verbal data with the non-verbal data. Thus, the writer sees that English Department respondents can communicate how Tokopedia promotes itself and how the non-verbal data support the verbal data than Engineering Department respondents. The writer thinks that Engineering Department respondents are not used to decode the implicit meanings from advertisement video.

Nonetheless, the writer discovers that English Department and Engineering Department's respondents have a similarity. The writer sees that the respondents from both departments mostly produce meanings according to their personal experiences. Thus, the writer thinks the personal association from the respondents helps them in interpreting data. For instance, R1 and R6 agree that the piled watch indicates the effort of the father. Thus, the writer sees the symbolical mode from both departments. Moreover, English Department and Engineering Department respondents mostly highlight the meaning of not wasting time from "GMMWM" video commercial. The writer sees that the respondents may have the similar point because the gap of age between the respondents is not big so that the respondents may produce the same point.

Overall findings, the writer sees that English Department respondents can explain how the verbal data relate to time and how the non-verbal data helps them to perceive the meaning rather than Engineering Department. Moreover, all English Department respondents can explicitly tell how Tokopedia encourages the audience to use or buy from its services. Engineering Departments respondents mostly cannot produce marketing message that Tokopedia implicitly provides in GMMWM advertisement video. Nevertheless, the writer finds similarities between English Department and Engineering Department respondents. Both departments' respondents show indexicality from their perceived meanings. The point that the respondents may deliver is also similar because the respondents do not have a big age difference. Hence, the writer thinks that different background knowledge affects how people process information. 


\section{CONCLUSION}

The writer concludes that this study reveals that background knowledge can indeed influence the process of perceived meaning. Each major has different perceptions in identifying how the "GMMWM" advertisement video emphasizes time and what role of Tokopedia in the commercial video. However, each respondent mostly involves their personal experiences in producing such meanings. The writer sees that the respondents mainly apply symbolic mode. The point of message that both departments' respondents also want to convey is about not wasting time. The writer also discovers how English Department's respondents mostly relate the data with their personal association in producing the meanings while Engineering Department's respondents interpret some data by looking at the cause and effect from the storyline. Thus, three of five respondents from Engineering Department are not able to think about how Tokopedia implicitly conveys marketing messages from the "GMMWM" commercial video. Nevertheless, the five respondents of English Department are able to tell how Tokopedia promotes its product through the advertisement video. The writer hopes that her findings can be resourceful and useful information for those who are interested in the field of marketing communication and Semiotics.

Finally, the writer recommends researching perceived meaning from the advertisements by looking at other factors such as age or gender to know more about how people perceive meanings. If there is a researcher who wants to analyze perceived meaning by looking at the background knowledge, the writer thinks the research may be better if the writer interviews Engineering Department respondents from a similar major like architecture, civil engineering, etc. The writer realizes that Engineering Department is broad so that the respondents may produce different perceived meanings because of different majors. The writer hopes that her research can be useful for future research on semiotics and marketing communication, especially for English Department students.

\section{REFERENCES}

Busen, S. M. S., \& Mustaffa, C. S. (2014). The Role of Interactive Advertisements in Developing Consumer-based Brand Equity: A Conceptual Discourse. Procedia - Social and behavioral sciences, 155, 98-103. doi: 10.1016/j.sbspro.2014.10.263

Chandler, D. (2007). Semiotics: The basics (2nd ed.). New York, USA: Routledge.

Gunawan, H. (2018, February 18). Ini pesan penting kampanye iklan tokopedia terbaru garapan flock untuk pemuda Indonesia. Retrieved from https://www.tribunnews.com/techno/2018/02/18/ini-pesan-penting-kampanye-iklantokopedia-terbaru-garapan-flock-untuk-pemuda-indonesia.

Leo, M. (2017). A Semiotic Analysis on The Perceived Meanings of Coca Cola "Anthem" Video Commercial. K@ta kita, 5(1),8-14. doi:10.9744/katakita/5/1/8.14

Mustansyir, R. (2003). Refleksi filosofis atas pekermbangan ilmu-Ilmu humaniora. Jurnal Filsafat 13(3), 209-217. https://jurnal.ugm.ac.id/wisdom/article/view/31794

Petrina, I. A. (2019). Natural White Pinkish Fairness Advertisement. K@ta kita, 7(1), 56. doi 10.9744/katakita.7.1.56-63

Saputra, F. D. (2017). The Concept of Happiness in DJarum 76 "Yang Penting Hepii..”. $K @ t a$ kita, 5(2), 27-37. doi 10.9744/katakita.5.2.27-37

Schreier, M. (2012). Qualitative content analysis in practice. London: SAGE Publications Ltd.

Woodside, A. G. (2010). Brand-customer storytelling theory and research: Introduction to a psychology \& marketing special issue. Psychology and marketing, 27(6), 531-5540/ doi:10.1002/mar.20342 